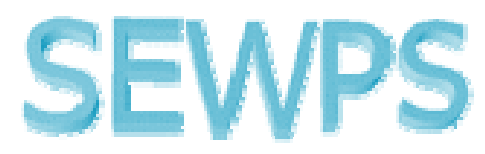

SPRU Electronic Working Paper Series

Paper No. 174

\title{
Learning and sharing in a Chinese high-technology cluster: a study of inter-firm and intra-firm knowledge flows between R\&D employees
}

\author{
Matias Ramirez* \& Xibao Li** \\ (*SPRU, **School of Economics \& Management, Tsinghua University )
}

\section{September 2008}


Learning and sharing in a Chinese high-technology cluster: A study of inter-firm and intra-firm knowledge flows between $R \& D$ employees.

\section{Matias Ramirez ${ }^{1}$ and Xibao $\mathbf{L i}^{2}$}

\section{August 2008}

JEL: D83, J24

Key words: learning, China, knowledge work, knowledge transfer

\footnotetext{
1 Matias Ramirez is a lecturer at SPRU - Science and Technology Policy Research, University of Sussex. For correspondence contact matias.ramirez@sussex.ac.uk.

${ }^{2}$ Xibao Li is an assistant professor at School of Economics and Management, Tsinghua University. lixibao@sem.tsinghua.edu.cn.
} 


\title{
Learning and sharing in a Chinese high-technology cluster: A study of inter-firm and intra-firm knowledge flows between $R \& D$ employees.
}

\begin{abstract}
Debates surrounding the nature of knowledge work and innovation concur that learning is associated with action oriented "learning-by-doing” (Brown and Duguid 2001, Lave and Wenger 1991). In an organisational context, an important part of learning may well be associated with some degree of sharing of this knowledge, either in the form of joint input into the learning process or peer review of knowledge output. Yet, although there is much rhetoric surrounding the importance of knowledge transfer and social networking, successfully instituting learning and sharing dynamics amongst knowledge workers, particularly when they involve inter-firm sharing, has been problematic. The fear of "leakiness" and the cost and time associated with establishing effective channels of communication can often deter effective knowledge sharing practices.

This paper discusses the results of a study of learning and sharing knowledge amongst R\&D employees working in China's largest science park, the Zhongguancun (ZGC) science park in Beijing. It discusses in detail the nature of jobs and the profile of R\&D employees engaged in learning and sharing and its relation to problemsolving capabilities of individuals in R\&D environments. Through the use of quantitative and qualitative evidence, a skills profile of "innovative" knowledge workers is built that, amongst other variables, controls for the ability to individuals to "translate" external knowledge to their firms. This highlights the importance of a division of labour associated with gatekeeping skills amongst Chinese R\&D employees. The implications of these and other findings are highly relevant for practitioners in R\&D environments developing new practices to enhance learning from participation in external networks.
\end{abstract}




\section{Introduction}

Successful strategies of innovation have increasingly been linked with more "open" business models (Chesbrough et al 2006, Best 2001) that emerge from the greater complexity, uncertainty and diversity of innovation processes (Hagedoorn 1996, Powell et al 1990, 1998). Open models of innovation in turn focus the attention on the ability of firms to learn from their participation in networks. R\&D employees (that will at time henceforth be referred to as knowledge workers) and the different network relationships they form within and outside of the firm are key factors in this process of learning (Granovetter 1973, Bailey et al 1998, Newel et al 2006, Assimakopoulos and Yan 2006).

This paper analyzes the relationship between learning and sharing and its impact on innovation, through a study of the problem-solving activities of R\&D employees. The study takes a practice-based perspective to learning (Brown and Duguid 1991, 2001), which stresses that learning is directly related to the degree of direct engagement of relevant actors in practitioner communities. The way in which these communities are conformed and their span across organisational and institutional frontiers will therefore play a crucial role in the type of learning that occurs.

This topic and the approach taken is highly relevant for emerging firms in the Chinese high-technology sector. While China has a critical mass of highly-qualified engineers and scientists, China's industrial structure has been described as highly hierarchical (Hutton 2007) and many of its firms depicted as having weak learning capabilities (Saxenian 2005). Important question marks therefore exist over the business models many firms follow and the degree and effectiveness of genuine interfirm collaboration. Indeed, at the level of R\&D employees, some studies suggest that very high levels of mobility amongst high-skilled Chinese employees is combined with low levels of loyalty towards their employers (Braun and Warner 2002). Important challenges therefore clearly exist to successfully instituting effective learning and sharing dynamics. Overcoming these may be the key to successful business models associated with innovation.

The paper firstly examines the practice-based approach to learning and sets this debate in terms of new approaches to innovation. Particular emphasis is placed on the move to "open" models of innovation that place a premium on relational approaches to learning and the brokering role that knowledge workers play at the frontier of the organisation. Section 3 develops a series of hypotheses that test assumptions regarding the skills profile of knowledge brokers undertaking problemsolving roles in R\&D. Section 4 and 5 discuss the quantitative methodology and the results of the regression models. Section 6 discusses the findings of interviews that flesh out and deepen the earlier survey findings and section 7 concludes.

\section{The practice-based approach to learning}

The majority of studies emphasize two social arenas that are relevant for learning around innovation. A Penrosian approach to the firm underlines the reliance on core, 
distinguishable and difficult to copy competencies within the organisation (Teece and Pisano 1994, Nelson and Winter 1984). Knowledge transfer in this context is assumed to be effective because it is underpinned by common organisational practices and culture from which specific and hard to copy competencies emerge. Learning built on network forms of coordination on the other hand, represent an alternative coordinating and governance mechanism (Thompson 2003) that stresses that social phenomena do not exist independently, but are in fact brought into existence by the relationships they establish. Learning therefore occurs in relation with, but not totally beholden to, the social milieu in which the development of knowledge takes place. In this context, the interface between organisational and networks forms of learning becomes crucial and Mintzberg's (1979) concept of “adhocracies” and Dyer and Nobeoka’s (2000) networked organisation typically reflect the development of organisational structures designed to learn in more "open" cross-disciplinary type environments.

The governance of firm and network contexts will clearly differ and bodies of literature from distinct epistemological traditions have developed diverse approaches to explain the mechanisms for coordinating knowledge. Nevertheless, an emergent literature taking a "practice-based perspective" (Brown and Duguid 2001, Lave and Wenger 1991, Barley and Orr 1997, Gherardi 2006) stresses the critical links that exist between the two. Rather than emphasize firms and networks as completely separate entities, this approach suggests that significant knowledge flows will take place within "cognitive communities" formed by practitioners and may be defined within and/or across organisational frontiers. Less emphasis is therefore placed on the conceptual difference between inter and intra-knowledge transfer, than on the common practices, channels of communication and the types of bonds that are formed.

This perspective therefore adopts a relational perspective to learning that emphasizes the connectedness of individuals and collective identities for problemsolving (Amin and Roberts 2008). Lave and Wenger's (1991) concept of "situated peripheral participation" in particular, emphasises the experience and in some cases the struggle individuals need to engage in to win the trust of a community or convince fellow members to embrace a perspective or strategy.

The above discussion is highly relevant for the development of HR practices in $R \& D$ environments concerned with generating and diffusing new ideas. Greater reliance on network forms of knowledge transfer requires a division of labour that encourages individuals to work at the frontier of the organisation, for example as "networks managers" (Powell 1998), "knowledge brokers” (Burt 2005) or "gatekeepers" (Macdonald and Williams 1992). Yet, in practice, well-thought out skills strategies to manage the interface with the firm's environment are often either ignored or not implemented effectively (Newel et. al 2006). Line managers in R\&D environments are usually under pressure to meet tight deadlines, which encourages specialization around narrow tasks rather than developing networking skills. The reluctance to develop networking skills however, may also reflect a tension, underlined by a perennial anxiety by managers that employees may divulge the “crown jewels" of the organisation's knowledge to rivals (Von Hippel 1994, Liebeskind 1996). Hence, management often attempt to restrict the porosity of the organisation to keep proprietary knowledge in-house and will typically develop employment practices that attempt to codify and leverage the specialist knowledge of these employees, in case they leave or divulge proprietary information. However, the degree to which knowledge in these environments is amenable to managerial control is in itself questionable (Scarbrough 1999), while Ramirez's (2007) study of R\&D employees in a major UK telecommunications firm suggests that organisational 
initiatives that run tangential to the strategies of career and skill formation of R\&D employees (often based on inter-firm careers) run a high risk of not being implemented effectively. The consequence is that the potential for learning is often missed in R\&D environments.

An alternative approach to managing skills and learning capabilities is to adopt a practice-based strategy to learning that emphasizes the overwhelmingly positive impact of knowledge flows across organisations. This recognizes that complex problems that require external learning can only be tackled when specific experiences are shared within practitioner communities that may overlap different organisations. The implication is that action-based learning can only take place when some knowledge is shared and divulged. Moreover, it is possible to hypothesise that projects requiring diversified knowledge will be served most effectively by knowledge workers that have a deep knowledge of, are embedded in and are sharing (or leveraging) knowledge with communities of practitioners outside the organisation. As Brown and Duguid (2001) state:

"As knowledge travels along networks built by practice, it leaks between firms along these conduits [...][T]rying to stop networks at the boundary of the organisation is very difficult....... moreover this may be a bad idea. The lines that let knowledge flow out, also let knowledge flow in, thus cutting off firm essential knowledge..” (2001, pp 207).

The implication is that organisations that over-emphasize closed proprietary knowledge may effectively disengage with the network structures of knowledge workers that span across organisations, or be limited to accessing generic knowledge that is less useful. This problem may be exacerbated where organisational barriers within the firm impede intra-firm knowledge transfer.

\section{Hypothesis}

The hypotheses below provide articulations of the proposition that the problemsolving capability of knowledge workers will be maximised through a broad workrelated experience and the ability to leverage external learning inside the organisation. This is built on involvement of the individual in problem-solving activities in the firm, being at the centre of key community and industry practice-based networks and assuming brokering role between the two. Hypothesis 1 below articulates the importance of firm-specific knowledge as a principal vehicle for learning on innovation projects. Long tenure and the position of seniority of R\&D employees are used as proxies for the degree of firm-specific experience. This is measured through seniority and tenure in the organisation.

\section{H1: R\&D employees with higher levels of seniority and tenure within the firm will play a more significant role in problem-solving on innovation processes in the firm than those with lower levels.}

Hypothesis 2 articulates the importance of experience of learning across different organisational contexts. In practical terms, R\&D employees that have labour market experience (years of work outside the firm) and a history of labour market mobility (i.e. learning-by-doing outside the organisation) will be more engaged in innovation within the firm. 


\section{H2: R\&D employees with a history of inter-firm mobility and labour market experience will play a more significant role in problem- solving on innovation projects than those who are less mobile and experienced.}

Hypotheses 3 and 4 test the practice-based approach to learning. This is firstly that the contribution of individual employees to innovation will be directly related to the degree of learning and sharing knowledge they are involved in. Hypothesis 4 goes on to propose that employees playing a knowledge brokering role, i.e. combine learning outside of the firm with sharing in their team and the wider enterprise in which they work, will also be more engaged in problem-solving on projects.

\section{H3: R\&D employees engaged in high levels of learning and sharing knowledge will play a more significant role in problem-solving on innovation projects than those with lower levels.}

\section{H4: R\&D employees most engaged leverage external knowledge inside the organisation will play a more significant role in problem-solving on innovation projects, than those less engaged.}

\section{Methodology and construction of variables for regression analysis}

The empirical investigation is undertaken through two principle methods. Firstly, the above hypotheses are tested through a survey undertaken in 2006 of 381 R\&D employees working in 71 Chinese high-technology firms located in Beijing's Zhongguancun (ZGC) high-technology park. Due to missing items, our empirical analysis was finally based on 289 observations.

Covering the northwest of Beijing, ZGC is China's first and largest hightechnology science park. Since its inception, spin-off companies from the large number of universities located in the ZGC area have become some of the best known in China, such as the Founder Group of Beijing University, the Tongfang group of Tsinghua University and Lenovo (formerly Legend). ICT is the dominant industrial sector in ZGC and accounts for 70 percent firms in ZGC, but there are also other significant players in bio-tech, advanced materials including optics and nanotechnology (Wang, 2000). Within ZGC there are 68 universities and 213 scientific research institutes, including the Chinese Academy of Sciences (academics of the Chinese Academy of Sciences and Chinese Academy of Engineering comprise 36\% of all academics in China (Wang 2000)). The survey findings are complemented by analysis of a series of detailed semi-structured interviews with R\&D managers and employees working in Chinese high-technology ICT firms, also located in the ZGC park. These interviews investigate in more detail how R\&D employees engage with information sources and knowledge actors from outside of the firm.

For the purposes of the survey, organisations approached to participate in the study included only indigenous Chinese ICT companies. The firms fulfilling the above criteria were chosen at random from a database of firms located in the park. A senior R\&D manager in each firm was approached and asked to nominate up to 10 $\mathrm{R} \& \mathrm{D}$ employees that had worked on a major innovation project that had taken place in the company in the last 3 years. These employees were then asked to answer questions on a survey and to submit these on-line. A quota system was used, whereby a target of participating firms was established and collection of data stopped once that 
target was reached. Each respondent was provided with a separate identity and used this in the survey to ensure each employee only provided responded to one survey.

The dependent variable, “degree of innovativeness" of individual R\&D employees, was based on the question "I have to regularly develop new solutions and procedures" describes a respondent's work in the innovation project. The item was measured on a five point scale from "not accurate" to "very accurate". Because the respondents all work in $R \& D$, it is assumed that the context for the development of solutions and procedures is associated with the introduction of new technology, or efforts to improve existing technology. The degree of learning is measured by responses to the question: "Have any of the following been important sources of learning for you about new technologies or managerial methods"? The degree of sharing is measured by responses to the question: "To what extent has sharing knowledge between you and any of the following influenced the output of the innovation project”? The latent sharing and learning variables were constructed through explanatory factor analysis and the factor loadings were then used to guide the construction of independent variables (See Table 1).

\section{Table 1 about here}

Because the dependent and independent variables are self-reported and collected from the same respondent, a common method variance problem may occur, which will cause systematic measurement error and bias the estimation. In order to check for this potential problem, we employed the Harman single factor test (Podsakoff and Organ, 1986) and conducted a factor analysis of both dependent and independent variables. Neither a single factor emerged nor did one general factor account for the majority of the covariance. Among five factors accounting for over 60 percent of the variance, factor 1 explained $21.8 \%$ percent of the variance. Therefore, we conclude that common method variance is not a serious problem in our data.

To test reliability of the latent variables, Cronbach's Alpha score was used. For an exploratory study, a value over 0.6 is generally acceptable to conclude internal consistency. In our data, all Alpha scores for the latent variables met this lenient criterion. We also examined the convergent validity of the latent variables with confirmatory factor analysis. Taking into consideration the ordinal nature of observed items, we performed this analysis with LISREL 8.8. The fit indices indicate that the measurement models fit the data very well (Chi-square $=128.28$; $\mathrm{p}$-value $=0.00$, Root Mean Square Error of Approximation $=0.06$, Goodness of Fit Index $=0.90$, NonNormed Fit Index $=0.96$, Comparative Fit Index $=0.95$ ). All observed items loaded on their respective latent variables, and each loading was significant at the 0.01 level $^{3}$.

Besides the variables reflecting knowledge learning and sharing patterns, five variables representing a respondent's skill profile were considered. Tenure measures the number of years the respondent has worked in current employer. Experience is the number of years since the respondent finishes his/her education minus years he/she has in current employment. Education is a dummy that measures if the respondent has

\footnotetext{
${ }^{3}$ To further assess the discriminant validity, we compared a model in which the correlation between a pair of latent variables was restricted to 1 with an unrestricted model. In our data, the pairwise tests among the four latent variables indicated that the fit of unrestricted model is always significantly better than that of restricted model, suggesting that the discriminant validity criteria were all satisfied. Thus, we combined the items measuring the same latent variables in our regression, and used the standardized scores as predictors.
} 
a master or higher level of education. Seniority is a dummy that measures whether the respondent holds a formal senior position within the organisation. We distinguish between those holding a managerial position and senior scientist/engineer on the one hand, from non-management technical and other employees within R\&D department on the other hand. Mobility is the number of previous jobs that the respondent has before she joins the current company. A maximum value of 5 is set as the limit of this measure.

\section{Table 2 about here}

Table 2 shows the correlation matrix and summary statistics for explanatory variables. Potential effects of multicollinearity were tested with Variance Inflation Factors (VIF). A value over 10 is normally regarded as an indication of serious concern of multicollinearity. In our case, VIF coefficients for all variables were less than 2 and thus multicollinearity is not taken to be a serious concern. Since the dependent variable "innovativeness" was measured in a five-point ordinal scale, the Order Probit regression technique was employed in estimation. As a robustness check, results based on various specifications are reported in Table 3. It is clear that our results are consistent and robust across model specifications. In the discussion below, the results refer to the full model 5.

\section{Insert table 3 about here}

\section{Profiling R\&D knowledge workers}

The results from Table 3 strongly supports hypotheses one and two. Deep knowledge of the firm, expressed in high levels of tenure and seniority, is positively associated with problem-solving in all 5 models. Experience and knowledge outside the firm, as represented by work experience in the wider labour market and a history of mobility, is similarly strongly significant and positive. Holding a postgraduate degree on the other hand is not significant. Broad hands-on knowledge clearly supports problem solving capability, abstract learning on the other hand, appears less directly related to innovativeness of individuals.

The model also provides partial support for hypotheses 3 and 4 . The most significant finding here is that external learning has a positive impact on the degree of problem-solving activity of knowledge workers in Chinese firms. The importance of learning from outside the firm is therefore also underlined, as is the importance of gatekeepers at the frontier of the organisation. Internal learning is not significant, probably because it is proxied by internal training, which rather than emphasising learning-by-doing, represents a formal method of learning which appears less effective. Knowledge sharing within the project team contributes positively to the problem-solving activity of individuals, although within the wider firm the impact is negative or non-significance, depending on the model used. This suggests there may be some silo-type hierarchical structuring in Chinese high-tech firms. Sharing outside of the firm through external sharing is not significant. Finally, the interaction terms search for specific relationships between learning and sharing. This shows a positive relationship effect of external-learning and team-sharing. This result supports hypothesis 4 , suggesting that a leverage effect exists between external learning and within-team sharing. It is significant that this leveraging does not exist with other sharing channels. 


\section{Differentiating external sources of learning}

The regression findings point to external learning as a generic activity that underlines the importance of learning from outside the organisation as a specific division of labour in R\&D in this group of Chinese firms. Although an important finding, the methodology gives us few clues regarding the diverse channels of external communication used by knowledge workers, the social make-up underpinning these, their effectiveness or indeed, whether employers actively encourage employees to devote time and effort to building a position within external communities of practitioners and translating this knowledge to the firm. The following section therefore builds on the earlier findings by investigating these questions through detailed semi-structured interviews with $R \& D$ employees in three Chinese high-tech firms located in the ZGC park.

The enterprises in which R\&D employees are employed are all important player firms in China's ICT sector. The interviews explore in more detail how these external networks differ and investigate the proposition that knowledge workers will be able to maximize their problem-solving ability (and translate this knowledge inside the company) according to the degree to which they actively participate channels of inter-firm communication. Interviewees were all asked the following question: "What is the most important information channel(s) used to learn from outside the company?” The interview protocol proceeded with semi-structured questions concerning the activities of knowledge workers themselves, the relative usefulness of these activities to their work and the attitude of the firm to engagement in external networks. The interview transcripts were analysed using NVIVO qualitative software that allowed coding of the respondent comments into relevant categories. These are shown in table 4 in the appendix, which summarizes the respondent replies. The following typology identifies 5 principal channels of communication used by employees for learning external beyond the organisations' frontier.

\section{Type 1}

\section{Unblocking routine information bottlenecks}

Many employees appear to use external sources of information to fill very specific information gaps; for example details of the wording of technological protocols, standards and patents. The information required involves minimal interaction on the part of users and generally involves access to specialist websites. However, there are a number of cases where relatively short conversations with ex-colleagues and personal contacts outside of the firm are used to help guide search strategies. This is particularly the case where the user has little context of the knowledge. DT1 for example, comments that, although it is available on the Internet, international standard protocols are a problem for him and, to save time, it is easier to get this information from ex-colleagues or friends. Table 4 shows that R\&D employees that identify type 1 form of interaction as their most important form of external learning, also mention its main advantage is time-saving rather than learning. Significantly, this accords with the rather narrow range of tasks these employees undertake and the emphasis on getting the job done quickly, rather than resolution of more complex problems. The interviews also suggest these knowledge workers tend to engage with external sources of information in an instrumental fashion, which requires little investment of their time and little reciprocal commitment.

\section{Type 2}




\section{Networks of practice: “weak link” personal contacts and anonymous internet boards}

An important source of external learning for R\&D employees involves relatively short-term interactions to help solve specific and specialized problems that emerge during the course of their work. These come firstly from personal contacts knowledge workers have developed in the past and with whom they have shared some common practices. They include ex-alumni, ex-colleagues and university supervisors and represent the "weak ties” first described by Granovetter (1973). Through these, reciprocal commitments are forged, that in a small number of cases, create the basis for more systematic future collaboration. Although these interactions will tend to be relatively short, they will also combine other topics of information exchange that range from general discussions on technological trends to job opportunities.

A second and it would appear, more extensively used communication channel for resolving immediate problems are web forums, such as Tsinghua University's BBS (see http://www.CSDN.net), whereby users place specific questions on a forum, that other forum members will reply to, usually in short one or two sentence answers. There is limited interaction and users will not usually be known to each other. A study of engineers in Chinese firms (Assimakopoulos and Yan, 2006) found that these forums are popular amongst IT workers. Due to the vast numbers of on-line users, they provide diverse information, and the response is efficient, partly because the problem does not have to be explained repeatedly and respondents tend to be professionals with knowledge of the job. A particular advantage of web forums is that they carry very little transaction cost, since users are not known to each other and interactions are short. This avoids renqing [moral obligation] (Gabrenya and Hwang, 1996) or heavy reciprocal ties, which are a feature of Guanxi [ties that oblige reciprocation] bonds in China.

Nevertheless, the limitations of web-based forums for resolving complex problems were also emphasized. It is argued that the material on the forums is too general (DT1), the level of technological sophistication is poor (DT3), while H1 suggests Chinese web-based forums are more closed than foreign ones. Significantly, it is the more experienced knowledge workers that emphasize the limitations of these forums for real learning.

A further example of the importance of weak links can be seen in the coming together of R\&D employees from different businesses at industry association meetings, trade fairs, university conferences and talks organised by leading firms in the locality to talk about new technological products, protocols and business models. By contrast to the above, that emerge as a result of bottom-up initiatives driven by employees themselves, this tends to be a top-down initiatives driven more clearly by the strategy and interests of the firm. Employees act as "scanners" for the firm, assessing the potential threat or opportunity of new technologies or management thinking for the company. It is the more experienced employees that appear to participate in these activities. Both managers and employees emphasize their importance, although there is also some criticism that these events are not sufficiently participative and therefore the information provided is too generic $(\mathrm{H} 2)$.

\section{Type 3}

\section{Formal functional knowledge transfer}

A fourth form of external learning takes place through the regular communication with the company's supply chain. Knowledge transfer occurs via the supplier as the 
company's employees are trained to use new equipment, whilst they in turn teach customers. Much learning is therefore static, associated with transferring, rather than developing, new knowledge. Into this category would also appear to fall formal communication with universities, which is associated principally with purchasing and learning the functionality of technologies. $\mathrm{H} 2$ suggests that communication amongst hardware firms relies on closer links and relationships between relevant actors because of the reduced number of companies in the sector. Moreover, close formal links in the supply chain can evolve into dynamic learning. Similarly, managers interviewed suggest that customers are an important source of learning (Zoi).

\section{Type 4}

\section{Inter-firm community of practice}

The interviews shed light on a "bottom-up" network formed by employees that work in different companies and whose members communicate regularly through a variety of mediums that include email, phone and occasionally face-to-face meetings. The interviewee comments that this network emerged from communication in web forums and evolved over time to discuss common points of interest amongst the participants. Through this process, a community of practice emerged that became more distinct and suited to the members interest. The usefulness of this network appears to have evolved beyond providing specific solutions to discussion around broader technological issues. As H2 suggests "they (stable forums) could not only solve my immediate problem, but also share knowledge about strengthening connection with market, helping us to evaluate our products, and know what kind of technology is the market prospect”. The gatekeeper role therefore emerges as important, as this participant defines the usefulness of this network in terms of the insights that may benefit the organisation. Echoing the point made by Lave and Wenger (1990), a crucial difference between the community of practice and formal firm-led external learning is that the former is shaped by the users and therefore has no hierarchical control. The functionality of the network has been shaped by the users who contribute as well as receive useful information. The community is thus built on a culture of sharing advice and experiences, regular communication and the use of a variety of mediums. Yet, few knowledge workers are involved in this sort of activity.

The above typology emphasizes the constellation of external networks and communication channels knowledge workers use to problem-solve for their work on innovation projects. In particular, the importance of "relational" networks is highlighted, in other words, the informal channels of communication built through the associations knowledge workers have built over time. These undoubtedly have the advantage of by-passing formal firm hierarchies that can slow down the flow of communication. These channels of communication also clearly play quite different problem-solving roles. Although type 1 and 2 networks mainly involve the transfer of codified information, they emphasize the crucial importance of access to broad sources of information and knowledge for quick and relatively costless solutions to resolve what are often information bottlenecks. These networks require little maintenance and investment, nevertheless the existence of a rich seam of informal networks and Internet forums can be essential for the solution of non-routine problems. By contrast, the community of practice is a network built with much time investment. Yet, its significance appears to lie less in the intensity of communication (in terms of regularity of contact) as in common understandings that have been built up over time to bridge the boundary between new market development in 
technologies and organisational knowledge. Thus the typology suggests a division of labour exists in these external networks.

\section{Discussion and conclusions}

The investigation in this paper has been built on the premise that a key component underpinning absorptive capability of organisations is the learning and sharing activities undertaken by knowledge workers within and outside of the borders of their employer. This emphasises the importance of brokering, but also poses questions regarding how firms manage the work employment relationship with key R\&D employees.

The empirical analysis firstly involved building a skill profile of Chinese knowledge workers that contributed to problem-solving on innovation projects. From this study, "innovativeness" (measured by "problem solving on innovation projects") of R\&D employees is associated with experience in the wider labour market and a history of inter-firm mobility. Wide experience appears to broaden the individual's skills portfolio. The importance of mobility may also be particular feature of the Chinese software sector, where small firms predominate, and work tends to be defined by finite projects and relatively transferable knowledge. The models suggest that innovativeness is also associated with high levels of firm-specific skills. External knowledge therefore appears important alongside a career commitment and experience of the firm. HR strategies therefore need to be directed towards building a leadership team that includes a portfolio of external and internal knowledge and experience.

A second aim of the paper has been to investigate the relationship between learning and sharing and the internal/external context within which this takes place. The regression analysis suggested that the development of new problem-solving routines and procedures in the firm is positively influenced by learning activity conducted outside the firm. Moreover, a key finding is the significant role of gatekeeping activity, as expressed through the interactive variable "external learning" and "internal sharing in the team" by the same individual. The regression analysis showed this made a significant and positive impact to problem solving. The implications are highly relevant, for they suggest problem-solving capabilities are driven in part by individuals that are able to learn from participation in external networks and to translate this knowledge in their team.

A further important finding is that external learning by innovative workers is shared within the team, rather than in the wider organization. This recalls Brown and Duguid's (2001) comment that organisations often create epistemic or bureaucratic barriers among different organizational communities, which makes leveraging of knowledge appear less effective outside of the team. This compartmentalization of knowledge inevitably will limit the effectiveness of knowledge transfer and can also make the organization vulnerable to the exit of key team members that act as gatekeepers to the outside.

A range of external communication channels used to gather and share information were also identified. These underlined firstly the growing importance of networks of practice, that are formed by relatively weak links in day-to-day problemsolving activities that extend beyond the boundaries of an organisation. Wide experience in the labour market and engagement in different types of external networks (scanning, formal networking) will be clearly an advantage and help solve day-to-day problems. 
However, a point not perhaps emphasized sufficiently in the literature and that appears consistently in the interviews, refers to the investment required by $R \& D$ employees to form effective networks of learning, such as communities of practice. A type of cost-benefit relationship appears to be in place. Some communication channels require little time investment and appear very useful for filling information gaps. Nevertheless, general frustration was expressed at the apparent ineffectiveness of these web portals, underlining their limited usefulness for more dynamic learning. On the other hand, the interviews demonstrated that building more effective personalised communities, involving the development of common dialogues, trust and shared practice with other users, requires up-front time investment, that not all linemanagers are in a position to absorb, even though this may increase the potential benefit of collaboration in the long-run.

In conclusion, it appears that the effectiveness of knowledge transfer activities undertaken by R\&D employees from external channels, depends partly on the experience and job role performed by employees within their organisation. Employees actively engaged in problem-solving activities with their networks outside the organisation should be encouraged to develop gatekeeping skills that allow useful knowledge and know-how outside of the company to be applied and used effectively within the organisation. However, the case studies also underlined that building effective conduits for knowledge transfer also require time investment by employees to shape these channels into useful learning tools for users. 


\section{References}

Amin, A. and Roberts, J. (2008) Knowing in action: Beyond communities of practice, Research Policy 37, 353-369.

Arrow, K. J. (1962) The Economic Implications of Learning- By-Doing, Rev. Econ. Stud. 28, 155-173.

Assimakopoulos, D. and Yan, J. (2006) Sources of knowledge acquisition for Chinese software engineers, $R \& D$ Management 36 (1) 97-106.

Bailey, W., Masson, R. and Raeside, R. (1998) Choosing successful technology development partners: a best practice model, International Journal of Technology Management, 15, 124-138.

Barley, S. and Orr, J. (Eds.) (1997) Between Craft and Science: Technical Work in the United States. Ithaca, NY: Cornell University Press.

Best, M. (2001) The New Competitive Advantage: The Renewal of American Industry, Oxford: Oxford University Press.

Braun, W. and Warner, M. (2002) Strategic human resource management in western multinationals in China” Personnel Review, 31, 5, 553-579.

Brown. John. S. and Duguid, P. (2001) Knowledge and Organisation: A SocialPractice Perspective, Organisation Science; 12, 2, 198-213.

Burt, R. (2005), Brokerage and Closure: An Introduction to Social Capital, Oxford: Oxford University Press.

Chesbrough, H.W., Vanhaverbeke, W. and West , J. (2006) Open Innovation: Researching a New Paradigm, Oxford: Oxford University Press.

Cohen, W. M. and Levinthal, D. A. (1990) Absorptive Capacity’ A New Perspective on Learning and Innovation, Administrative Science Quarterly, 35, 128-152.

Davenport, T. (2002) "Can you boost knowledge work's impact on the bottom line?", Management Update, 7, 11, 3-5.

Drucker, P. (1999) Knowledge-worker productivity: the biggest challenge, California Management Review, 41, 2, 79-85.

Dyer, J.H. and Nobeoka, K. (2000) Creating and managing a knowledge-sharing network: the Toyota case. Strategic, Management Journal 21, 345-67.

Gabrenya,W.K. and Hwang, K.K. (1996) Chinese social interaction: harmony and hierarchy on the good earth. In Bond, M.H. (ed.), Handbook of Chinese Psychology. Hong Kong: Oxford University Press.

Gherardi, S. (2006) Organizational Knowledge: The Texture of Workplace 
Learning. Oxford: Blackwell Publishing.

Granovetter, M. (1973) The strength of weak ties, American Journal of Sociology, 78, 6, 1360-1380.

Hagedoorn , J, (1996) Trends and patterns in strategic technology partnering since the early seventies, Review of Industrial Organization, 11, 601-16.

Hutton, W. (2007) The Writing on the Wall and the West in the $21^{\text {st }}$ Century, London: Little Brown.

Lam, A. (2000) Tacit knowledge, organisational learning and societal institutions: an integrated framework, Organisational Studies, 21, 487-513.

Lam, A. (2005) Organisational Innovation. In Fageberg, J., Mowery, D., and Nelson, R. R, (Eds), Oxford Handbook of Innovation, Oxford: Oxford University Press.

Lave, J. and Wenger, (1991) Situated Learning: Legitimate Peripheral Participation, Cambridge, UK: Cambridge University Press.

Leonard-Barton, D. (1995) Wellsprings of Knowledge: Building and Sustaining the Sources of Innovation, Boston: Harvard Business School Press.

Liebeskind, J. P. (1996) Knowledge, strategy and the theory of the firm, Strategic Management Journal, 17, (Winter Special Issue), 93-107.

Lorenz, E. (2003) Inter-organisatrional trust, boundary spanners and community of practice. In Burchel, B. Deakin, S. Michie, J and Rubery J., (Eds), Systems of Production: Markets, organisations and performance, London: Routledge, 60-73.

Macdonald, S., Williams, C. (1992) Survival of the Gatekeeper. Proceedings of the international product development conference on new approaches to development and engineering. EIASM, Brussels, 349-364. 18-19 May.

Mintzberg , H. (1979), The Structure of Organisations, Englewood Cliffs, NJ: Prentice Hall.

Nelson, R and Winter S. (1982), An evolutionary theory of economic change, Cambridge, Mass: Belknap Press.

Newel, S., Bresnen, M., Edelman, L., Scarbrough, H. and Swan, J. (2006) Sharing knowledge across projects, Management Learning, 37, 2, 167-185.

Podsakoff, P. and Organ, D. (1986) Self-reports in organizational research: Problems and prospects. Journal of Management, 12, 531-544.

Powell, W. (1990) Neither market nor hierarch: network forms of organisation, Research in Organisational Behavior, 12, 295-336. 
Powell, W. (1998) Learning from Collaboration: Knowledge Networks in Biotechnology and Pharmaceutical Industries. California Management Review $\mathbf{4 0}$ (Spring), 228-241.

Ramasamy, B., Goh, K.W., Yeung, Mathwe, C.H. (2006) Is Guanxi (relationship building) a bridge to knowledge transfer? Journal of Business Research 59,1, 130-139.

Ramirez, M. (2007) Redefining Firm Competencies, Innovation and Labour Mobility: A Case Study in Telecommunications Services, Industry and Innovation, 14, 3, 325347.

Redding, S.G. and Ng, M. (1982) The role of 'face' in the organisational perceptions of Chinese managers. Organisation Studies 3, 201-19.

Saxenian, A. (2005) Government and Guanxi: The Chinese software industry in transition. In: The Software Industry in Emerging Markets, Simon Commander. (Eds.). Edward Elgar.

Scarbrough. H, (1999) Knowledge as Work, Conflicts in the Management of Knowledge Workers, Technology Analysis and Strategic Forecasting, 11, 1, 5-16.

Teece, D.G. and Pisano, G. (1994) The Dynamic Capabilities of Firms: An Introduction, Industrial and Corporate Change, 3, 3, 537-56.

Thompson, G.F., (2003) Between Hierarchies and Markets: The Logic and Limits of Network Forms of Organisation, Oxford University Press: Oxford.

Von Hippell, E. (1994), "Sticky information” and the locus of problem-solving: implications for innovation”, Management Sci, 40, 4, 423-439.

Wang, S., Wu, Y. and Li, Y. (2000) Development of Technopoles in China, Asia Pacific Viewpoint, 39, 3, 281-301. 
Table 1 Measures and Variable Construction

\begin{tabular}{lll}
\hline Variables & Questions & $\begin{array}{c}\text { Cronbach's } \\
\text { Alpha }\end{array}$ \\
\hline $\begin{array}{l}\text { How would you describe your work in the } \\
\text { "innovation project"? A }\end{array}$ & $\begin{array}{l}\text { I have to regularly develop new solutions and } \\
\text { procedures }\end{array}$ \\
Innovativeness & $\begin{array}{l}\text { To what extent has sharing knowledge between } \\
\text { you and any of the following influenced the output } \\
\text { of the innovation project? }\end{array}$ \\
Your project team \\
Share-Team \\
Share-Firm
\end{tabular}

Have any of the following been important sources of learning for you about new technologies or managerial methods?

Learn-Internal Internal Training

Learn-External

1. Attending conference

2. Communication with people outside the company (e.g. group email, message board chat room

3. Informal communication with people you know outside the company dealing with similar problems

4. Overseas visits

5. Training outside of company inside the ZGC Park

\footnotetext{
A Measured on a four-point likert scale: 0, "not accurate", 1, "slightly accurate", 2, "moderately accurate", 3, "very accurate".

B Measured on a four-point likert scale: 0, "no knowledge shared", 1, "small influence", 2, "some influence", 3, "very influential".

B Measured on a four-point likert scale: 0, "not important", 1, "slightly important", 2, "moderately important", 3, "very important l".
} 
Table 2 Correlation Matrix and Summary Statistics

\begin{tabular}{|c|c|c|c|c|c|c|c|c|c|c|c|}
\hline & $\begin{array}{l}\text { Log } \\
\text { (Tenure) }\end{array}$ & $\begin{array}{l}\text { Log } \\
\text { (Exper- } \\
\text { ience) }\end{array}$ & Education & Seniority & Mobility & $\begin{array}{l}\text { Share- } \\
\text { Team }\end{array}$ & $\begin{array}{l}\text { Share- } \\
\text { Firm }\end{array}$ & $\begin{array}{l}\text { Share- } \\
\text { Formal }\end{array}$ & $\begin{array}{l}\text { Share- } \\
\text { Informal }\end{array}$ & $\begin{array}{l}\text { Learn- } \\
\text { Internal }\end{array}$ & $\begin{array}{l}\text { Learn- } \\
\text { External }\end{array}$ \\
\hline & 1 & 2 & 3 & 4 & 5 & 6 & 7 & 8 & 9 & 10 & 11 \\
\hline 2 & -0.29 ** & & & & & & & & & & \\
\hline 3 & 0.07 & 0.05 & & & & & & & & & \\
\hline 4 & $0.22^{\star *}$ & $0.17^{\star \star *}$ & 0.14 * & & & & & & & & \\
\hline 5 & $-0.16^{\star *}$ & 0.33 ** & 0.04 & $0.12^{\star}$ & & & & & & & \\
\hline 6 & 0.00 & -0.01 & 0.00 & $0.12^{*}$ & $0.25^{\star \star}$ & & & & & & \\
\hline 7 & 0.10 & -0.08 & 0.04 & 0.07 & -0.02 & $0.21^{\star \star}$ & & & & & \\
\hline 8 & 0.00 & -0.03 & 0.08 & 0.02 & $-0.14^{*}$ & $-0.13^{\star}$ & $0.49 * *$ & & & & \\
\hline 9 & -0.10 & 0.03 & -0.04 & 0.06 & 0.01 & $-0.14^{\star}$ & 0.09 & $0.41^{\star *}$ & & & \\
\hline 10 & 0.07 & -0.05 & -0.06 & 0.03 & 0.03 & $0.12^{\star}$ & $0.16^{\star *}$ & 0.07 & -0.10 & & \\
\hline 11 & 0.00 & -0.10 & -0.05 & -0.06 & -0.03 & $0.21^{\star *}$ & $0.21^{* \star}$ & 0.06 & -0.03 & $0.31^{\star \star}$ & \\
\hline Mean & 0.51 & 0.00 & 0.27 & 0.40 & 0.57 & 0 & 0 & 0 & 0 & 0 & 0 \\
\hline S.D. & 0.90 & 1.49 & 0.45 & 0.49 & 0.91 & 1 & 1 & 1 & 1 & 1 & 1 \\
\hline
\end{tabular}


Table 3 Results from Order Probit Models

\begin{tabular}{|c|c|c|c|c|c|}
\hline COEFFICIENT & (1) & $(2)$ & (3) & $(4)$ & (5) \\
\hline \multicolumn{6}{|l|}{ Main Predictors } \\
\hline \multirow[t]{2}{*}{ Log (Tenure) } & $0.196^{\star \star}$ & $0.195^{\star \star}$ & $0.200^{\star *}$ & $0.197^{\star \star}$ & $0.191^{\star \star}$ \\
\hline & $(2.43)$ & $(2.42)$ & $(2.49)$ & $(2.44)$ & $(2.36)$ \\
\hline \multirow[t]{2}{*}{ Log (Experience) } & $0.107^{* *}$ & $0.112^{\star \star}$ & $0.113^{\star \star}$ & $0.114^{\star \star}$ & $0.111^{\star *}$ \\
\hline & $(2.16)$ & $(2.26)$ & $(2.26)$ & $(2.29)$ & $(2.23)$ \\
\hline \multirow[t]{2}{*}{ Education } & 0.005 & 0.007 & 0.018 & 0.012 & 0.028 \\
\hline & $(0.04)$ & $(0.05)$ & $(0.12)$ & $(0.08)$ & $(0.19)$ \\
\hline \multirow[t]{2}{*}{ Seniority } & $0.300^{\star *}$ & $0.279 *$ & $0.290^{* *}$ & $0.277^{*}$ & $0.277^{*}$ \\
\hline & $(2.10)$ & $(1.94)$ & $(2.02)$ & $(1.92)$ & $(1.90)$ \\
\hline \multirow[t]{2}{*}{ Mobility } & $0.208^{\star \star}$ & $0.222^{\star \star}$ & $0.208^{\star \star}$ & $0.221^{\star \star}$ & $0.224^{\star \star}$ \\
\hline & $(2.54)$ & $(2.68)$ & $(2.53)$ & $(2.67)$ & $(2.70)$ \\
\hline \multirow{2}{*}{ Share-Team } & $0.179 * \star$ & $0.207^{\star \star}$ & $0.182^{\star \star}$ & $0.206^{\star \star}$ & 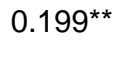 \\
\hline & $(2.57)$ & $(2.90)$ & $(2.60)$ & $(2.89)$ & $(2.77)$ \\
\hline \multirow[t]{2}{*}{ Share-Firm } & $-0.142^{*}$ & -0.134 & $-0.147^{\star}$ & $-0.137^{*}$ & -0.133 \\
\hline & $(-1.73)$ & $(-1.63)$ & $(-1.79)$ & $(-1.66)$ & $(-1.59)$ \\
\hline \multirow[t]{2}{*}{ Share-Formal } & 0.084 & 0.068 & 0.082 & 0.068 & 0.062 \\
\hline & $(0.99)$ & $(0.79)$ & $(0.96)$ & $(0.79)$ & $(0.69)$ \\
\hline \multirow[t]{2}{*}{ Share-Informal } & 0.016 & 0.023 & 0.017 & 0.023 & 0.016 \\
\hline & $(0.22)$ & $(0.31)$ & $(0.23)$ & $(0.31)$ & $(0.21)$ \\
\hline \multirow[t]{2}{*}{ Learn-Internal } & 0.029 & 0.017 & 0.021 & 0.014 & 0.013 \\
\hline & $(0.40)$ & $(0.23)$ & $(0.29)$ & $(0.20)$ & $(0.17)$ \\
\hline \multirow[t]{2}{*}{ Learn-External } & $0.196^{\star *}$ & $0.205^{\star \star}$ & $0.205^{\star \star}$ & $0.207^{\star \star}$ & $0.206^{\star \star}$ \\
\hline & $(2.73)$ & $(2.84)$ & $(2.83)$ & $(2.86)$ & $(2.77)$ \\
\hline \multicolumn{6}{|l|}{ Interaction Terms } \\
\hline \multirow{2}{*}{$\begin{array}{l}\text { Share-Team * Learn- } \\
\text { External }\end{array}$} & & $0.134^{*}$ & & $0.123^{\star}$ & $0.132^{*}$ \\
\hline & & $(1.91)$ & & $(1.65)$ & $(1.76)$ \\
\hline \multirow{2}{*}{$\begin{array}{l}\text { Share-Firm * Learn- } \\
\text { External }\end{array}$} & & & 0.064 & 0.028 & -0.001 \\
\hline & & & $(1.07)$ & $(0.45)$ & $(-0.01)$ \\
\hline \multirow{2}{*}{$\begin{array}{l}\text { Share-Formal * Learn- } \\
\text { External }\end{array}$} & & & & & 0.045 \\
\hline & & & & & $(0.55)$ \\
\hline \multirow{2}{*}{$\begin{array}{l}\text { Share-Informal * Learn- } \\
\text { External }\end{array}$} & & & & & 0.041 \\
\hline & & & & & $(0.50)$ \\
\hline \multirow[t]{2}{*}{ Cut Point 1} & $-1.268^{\star \star}$ & $-1.252^{\star \star}$ & $-1.257^{\star \star}$ & $-1.249 * \star$ & -1.250 ** \\
\hline & $(-9.45)$ & $(-9.30)$ & $(-9.34)$ & $(-9.25)$ & $(-9.25)$ \\
\hline \multirow[t]{2}{*}{ Cut Point 2} & -0.144 & -0.123 & -0.132 & -0.119 & -0.119 \\
\hline & $(-1.29)$ & $(-1.10)$ & $(-1.18)$ & $(-1.07)$ & $(-1.07)$ \\
\hline \multirow[t]{2}{*}{ Cut Point 3} & $1.338^{\star \star}$ & $1.373^{\star \star}$ & $1.355^{\star \star}$ & $1.378^{\star \star}$ & $1.381^{\star \star}$ \\
\hline & $(10.3)$ & $(10.4)$ & $(10.3)$ & $(10.4)$ & $(10.4)$ \\
\hline Log Likelihood & -323.9 & -322.0 & -323.3 & -321.9 & -321.4 \\
\hline Model Chi-Squre & 48.67 & 52.34 & 49.83 & 52.54 & 53.71 \\
\hline Model p-value & $<.0001$ & $<.0001$ & $<.0001$ & $<.0001$ & $<.0001$ \\
\hline
\end{tabular}

$\mathrm{N}=289$; z statistics in parentheses; ${ }^{* *} \mathrm{p}<0.05$, ${ }^{*} \mathrm{p}<0.1$. 


\section{Appendix}

\section{Table 4}

\begin{tabular}{|c|c|c|c|c|c|c|c|}
\hline $\begin{array}{l}\text { Company } \\
\text { details }\end{array}$ & $\begin{array}{l}\text { Enterprise } \\
\text { view on } \\
\text { employee } \\
\text { networks }\end{array}$ & $\begin{array}{l}\text { Employ } \\
\text { ee }\end{array}$ & $\begin{array}{l}\text { R\&D employee } \\
\text { tenure tasks and } \\
\text { position in } \\
\text { company }\end{array}$ & $\begin{array}{l}\text { Creativity at } \\
\text { work }\end{array}$ & $\begin{array}{l}\text { Supply chain } \\
\text { learning and } \\
\text { sharing }\end{array}$ & $\begin{array}{l}\text { Do you resort to } \\
\text { personal } \\
\text { networks to help } \\
\text { your work? }\end{array}$ & $\begin{array}{l}\text { Usefulness of virtual networks for } \\
\text { learning and sharing? }\end{array}$ \\
\hline \multirow[t]{3}{*}{\begin{tabular}{|l|} 
DT2000 \\
$(1500$ \\
employed \\
in R\&D) \\
$(10,000$ in \\
group \\
Telecom \\
hardware \\
and \\
software \\
State \\
owned. \\
\end{tabular}} & $\begin{array}{l}\text { Employees } \\
\text { allowed to } \\
\text { contact } \\
\text { university as } \\
\text { long as } \\
\text { company } \\
\text { secrets are } \\
\text { not shared. }\end{array}$ & DT1 & $\begin{array}{l}2 \text { years, Coding, } \\
\text { non-manager. }\end{array}$ & $\begin{array}{l}\text { Narrow } \\
\text { range of } \\
\text { skills }\end{array}$ & $\begin{array}{l}\text { Introduction of } \\
\text { chip technology } \\
\text { in its early } \\
\text { stages with } \\
\text { Peking } \\
\text { university. } \\
\text { Dropped off as } \\
\text { technology } \\
\text { mastered }\end{array}$ & No & Web material too general. \\
\hline & & DT2 & $\begin{array}{l}5 \text { years, Concept } \\
\text { designer, non } \\
\text { manager. }\end{array}$ & $\begin{array}{l}\text { Specialized } \\
\text { skills } \\
\text { associated } \\
\text { with the job }\end{array}$ & $\begin{array}{l}\text { With suppliers } \\
\text { as part of } \\
\text { development } \\
\text { on chips. }\end{array}$ & $\begin{array}{l}\text { Call some class } \\
\text { mates }\end{array}$ & $\begin{array}{l}\text { Web material too general but } \\
\text { some saving of time. }\end{array}$ \\
\hline & & DT3 & $\begin{array}{l}5 \text { years, Designer, } \\
\text { non-manager. }\end{array}$ & $\begin{array}{l}\text { Hardware } \\
\text { and flexible } \\
\text { tasks }\end{array}$ & $\begin{array}{l}\text { Hardware } \\
\text { communication } \\
\text { with suppliers, } \\
\text { face-to-face } \\
\text { meetings if } \\
\text { possible. }\end{array}$ & $\begin{array}{l}\text { Ex-colleagues } \\
\text { from Automatic } \\
\text { Research } \\
\text { Institute (founder } \\
\text { body) and with } \\
\text { my supervisor. }\end{array}$ & $\begin{array}{l}\text { Level of hardware forums is poor. } \\
\text { Technological board of company } \\
\text { not very useful. Beijing is very big } \\
\text { and we don't have time to travel } \\
\text { to meet. }\end{array}$ \\
\hline \multirow{2}{*}{\begin{tabular}{|l|} 
Hang400 \\
(150 in \\
R\&D) \\
Telecom \\
software \\
Private. \\
Spin-off \\
from \\
research \\
institute, \\
which \\
owns \\
minority \\
share. \\
\end{tabular}} & $\begin{array}{l}\text { Little } \\
\text { attention is } \\
\text { paid to the } \\
\text { personal } \\
\text { networks of } \\
\text { engineers, } \\
\text { but they are } \\
\text { welcomed. }\end{array}$ & $\mathrm{H} 1$ & $\begin{array}{l}7 \text { years, Software } \\
\text { project manager, } \\
\text { conceptualisation, } \\
\text { requirement } \\
\text { analysis and } \\
\text { coding. Non- } \\
\text { manager }\end{array}$ & $\begin{array}{l}\text { Software } \\
\text { specialized } \\
\text { skills } \\
\text { associated } \\
\text { with the job }\end{array}$ & $\begin{array}{l}\text { Will meet with } \\
\text { hardware } \\
\text { suppliers if } \\
\text { problem cannot } \\
\text { be resolved. } \\
\text { Customers. } \\
\text { Character } \\
\text { Recognition } \\
\text { Lab (founder) }\end{array}$ & \begin{tabular}{|l|} 
Likes direct \\
communication \\
and forums. Gets \\
together with 3-5 \\
people. \\
Developed own \\
on-line forum.
\end{tabular} & $\begin{array}{l}\text { The share of technology is not } \\
\text { enough in domestic websites, } \\
\text { and not as open as foreign ones. } \\
\text { Seldom participate in discussion } \\
\text { boards. Company technology in } \\
\text { recognition software is too } \\
\text { specialized, no one to talk too. }\end{array}$ \\
\hline & & $\mathrm{H} 2$ & $\begin{array}{l}3 \text { years, hardware } \\
\text { conceptualisation, } \\
\text { requirement } \\
\text { analysis, coding, } \\
\text { testing and } \\
\text { support, Manager }\end{array}$ & \begin{tabular}{|l|} 
Developed \\
patent as \\
inventor. \\
Special \\
interest in \\
customer \\
service
\end{tabular} & $\begin{array}{l}\text { Customers and } \\
\text { suppliers, but } \\
\text { hardware } \\
\text { involves longer } \\
\text { and closer links } \\
\text { than software. } \\
\text { Enterprise } \\
\text { customers to } \\
\text { develop new } \\
\text { products }\end{array}$ & $\begin{array}{l}\text { With some ex- } \\
\text { alumni }\end{array}$ & $\begin{array}{l}\text { ZGC exhibition centre not very } \\
\text { useful because too general. } \\
\text { Sometimes I get advertisement } \\
\text { for conferences, for example, } \\
\text { from CCID NET (a platform for IT } \\
\text { service). Even if I went to those } \\
\text { conferences, there was more } \\
\text { listening and less communication. } \\
\text { Direct communication and forums } \\
\text { are more useful, I set up my own } \\
\text { one. This forum can strengthen } \\
\text { the connection with market, help } \\
\text { me evaluate our products, and } \\
\text { know what kind of technology is } \\
\text { market prospect }\end{array}$ \\
\hline
\end{tabular}


Table 4 con't

\begin{tabular}{|c|c|c|c|c|c|c|c|}
\hline \multirow[t]{2}{*}{\begin{tabular}{|l|} 
Zoi \\
Telecom \\
software/hardware \\
(80\% software) \\
Private. Spin- off \\
from research \\
institute
\end{tabular}} & \multirow{2}{*}{\multicolumn{2}{|c|}{\begin{tabular}{|l|l} 
Communication & Z1 \\
outside \\
company is \\
specialised \\
activity, not for \\
most R\&D \\
staff. \\
\\
The skills our \\
company \\
values are very \\
specialized for \\
some people \\
and broad \\
knowledge for \\
others.
\end{tabular}}} & $\begin{array}{l}2 \text { years. } \\
\text { Requirement } \\
\text { analysis, } \\
\text { coding, testing } \\
\text { and support. } \\
\text { Manager. }\end{array}$ & $\begin{array}{l}\text { Wants to } \\
\text { start own } \\
\text { undertaking } \\
\text { or } \\
\text { entrepreneur. }\end{array}$ & $\begin{array}{l}\text { Some } \\
\text { learning takes } \\
\text { place from } \\
\text { customers }\end{array}$ & $\begin{array}{l}\text { Often meet alumni } \\
\text { but don't talk about } \\
\text { technology because I } \\
\text { work in applied } \\
\text { Maths and most of } \\
\text { my colleagues have } \\
\text { moved on. Meet } \\
\text { some ex-colleagues } \\
\text { now and then and } \\
\text { can analyze } \\
\text { problems more } \\
\text { clearly through e- } \\
\text { mail. }\end{array}$ & $\begin{array}{l}\text { Web forums useful } \\
\text { for getting } \\
\text { information on } \\
\text { protocols. }\end{array}$ \\
\hline & & & $\begin{array}{l}1 \text { year, } \\
\text { requirement } \\
\text { analysis, } \\
\text { coding, } \\
\text { testing and } \\
\text { support. }\end{array}$ & $\begin{array}{l}\text { Specialized } \\
\text { skills } \\
\text { associated } \\
\text { with the job }\end{array}$ & $\begin{array}{l}\text { Transferring } \\
\text { know-how to } \\
\text { customers on } \\
\text { the use of } \\
\text { new products. }\end{array}$ & $\begin{array}{l}\text { Communicate with } \\
\text { ex-alumna. We talk } \\
\text { about future } \\
\text { development or life } \\
\text { plan etc, but seldom } \\
\text { technology. We also } \\
\text { exchange some new } \\
\text { opportunities, both } \\
\text { on technology and } \\
\text { work position. }\end{array}$ & $\begin{array}{l}\text { Seldom use them } \\
\text { except for looking } \\
\text { up some details of } \\
\text { protocols } \\
\text { occasionally. I have } \\
\text { little time. }\end{array}$ \\
\hline
\end{tabular}

